\title{
Heuristics Behavior of Stock Investors on the Indonesian Stock Exchange During the Covid-19 Pandemic
}

\author{
Liliana Inggrit Wijaya ${ }^{1} \&$ Zunairoh $^{2 *}$
}

\author{
${ }^{1}$ University of Surabaya, Surabaya, Indonesia \\ ${ }^{2}$ University of Surabaya, Surabaya, Indonesia \\ ${ }^{*}$ Corresponding author. Email: zunairoh@staff.ubaya.ac.id
}

\begin{abstract}
The Covid-19 pandemic has caused funds invested primarily for investments in risky assets, like stock instruments traded on the capital market, to become more fluctuating. Behavioral finance has an essential role in finance, namely understanding human behavior, including investor behavior. This study aims to analyze the heuristic behavior of investors in deciding stock investments in the Indonesia Stock Exchange during the Covid-19 pandemic. The methodology used was factor analysis to explain the heuristic behavior considered by individual investors in making investment decisions by conducting literature studies, surveys, distributing questionnaires to investors, analyzing and discussing research results. The study results show two factors of heuristic behavior that individual investors should consider in making investment decisions: experience and learning orientation factors.
\end{abstract}

Keywords: The Covid-19 Pandemic, Behavioral Finance, Investment Decisions, Heuristics Theory.

\section{INTRODUCTION}

The first coronavirus (Covid-19) case was reported in China at the end of 2019. While the Republic of Indonesia's President reported the first Covid-19 case in Indonesia on March 2, 2020 (www.who.int, 2021). The Covid-19 pandemic has the potential to disrupt global economic activities, and in fact, it has disrupted all countries worldwide, including Indonesia. In Q2 and Q3 of 2020, Indonesia experienced negative economic growth of $5.32 \%$ and $-3.49 \%$, respectively (World Bank, 2020). This condition can affect the investment funds, especially for investments in risky assets such as stock instruments traded on the capital market. However, the impact experienced by individual investors varies according to the investor behavior in taking risks (investor risk-taking behavior).
Recent studies in financial behavior show that investor perception can indicate their investment decisions (Hoffmann, Post, \& Pennings, 2013). Study in America and Europe in 2008-2009 shows investor's investment decisions during the economic crisis have a different pattern (Hoffmann et al., 2013). Overall, during the economic crisis, investors continue to trade stocks actively and do not reduce the risk of investment portfolios during the crisis because investors use the crisis as an excellent opportunity to enter the stock market.

Investor's willingness to accept risk is generally determined by personal characteristics and risk-facing behavior, like decisions taken by an individual throughout his life (Istanbul, Yurttadur, \& Ozcelik, 2019). The characteristics of investors in this study include gender, age, family status, education, type and length 
of work, length and value of the investment, and income.

The decisions made by investors remain challenging for some financial analysts to understand. Many global securities companies and financial institutions turn out to provide recommendations that sometimes do not "match" the reality. Forecasting methods based on conventional financial theory do not provide satisfactory results to denote stock price movements. This situation strongly reinforces the need to explore behavioral factors that will influence an individual investor's decision-making process. Three reasons make behavioral finance is essential and interesting to be applied on the Indonesia Stock Exchange. Firstly, behavioral finance is still accepted as a feasible model (Méndez \& Arias, 2021). Secondly, the number of studies that employ behavioral finance for frontier and emerging markets, such as in Indonesia, is far less than the studies that have been conducted in developed markets. Thirdly, behavioral finance studies that examine investor behavioral aspects in choosing stocks in a pandemic are still limited. Based on these three reasons, the main objective of this study is to obtain an overview of the behavioral factors that individual investors consider when making stock investment decisions in companies listed on the Indonesia Stock Exchange during the Covid-19 pandemic. This study fills the gaps in the existing literature by examining behavioral factors of individual investors in deciding stock investments in companies listed on the Indonesia Stock Exchange during the Covid-19 pandemic.

\subsection{Behavioral finance vs traditional finance}

Based on the fact that humans are not always rational, financial decisions can also be driven by preconceptions of behavior. Therefore, the study of behavioral finance has an essential role in finance, where cognitive psychology is aimed at understanding human behavior, including investor behavior. Individuals not only use ratio in decision making but also emotional and behavioral elements (Bousselmi, Sentis, \& Willinger, 2019). That is, behavioral finance shows that conventional financial theory pays less attention to how people actually make decisions and that these people have different decisions in investing.

\subsection{Investor Behavior}

Two perspectives of rational and irrational are used to analyze events in the capital market. Rational investors prefer mathematical or statistical calculations before making risky investment decisions. While irrational investors invest only based on instinct or follow, are not accustomed to analyzing the details of the situation and conditions of the sector, and even believe in the mystical aspects of the investment being offered (Fan, 2020)

According to Batmunkh, Choijil, Paulo, Espinosa-méndez, \& Wong (2020) behavioral finance relies on psychological aspects, where the human decision-making process is based on a number of cognitive illusions, one of which is an illusion that causes a heuristic decision-making process (Rihards, Savin, \& Lublóy, 2019).

The heuristic theory is a valuable rule of thumb for decision-making in uncertain conditions. Individuals who fail to assess probability ideally due to limited time and information will tend to be heuristic in making decisions. As a result, individuals will collect information with shortcuts so that the decision-making process becomes easier, simpler, and more efficient. In this study, heuristics has four dimensions: representativeness, anchoring, ability bias, and overconfidence. The dimensions of representativeness, restraint, and ability bias are more related to past events. For example, if a company has consistently performed well in the past, it tends to assume that in the future, the company will also be performing well so that it can underreact essential information and stock price changes. In addition, one dimension in the heuristic theory is overconfidence, where investors are too confident and exaggerate their abilities and knowledge to seek higher profits. 
In a pandemic, uncertainty in everything occurs. On the other hand, the absence of factual information leads investors to consider past trends when making investment decisions. Additionally, a pandemic situation makes information and certainty challenging to predict; thus, investors rely more on information available from close friends and relatives in making investment decisions. As a result, heuristic theories are closely related to investors' trading decisions during a pandemic.

\subsection{Stock trading decisions}

In principle, there are two important decisions in stock trading, namely buying and selling, because these two decisions are related to a series of other decisions.

From a behavioral finance point of view, investor behavior has an impact on selling and buying decisions at different levels. The pandemic is considered a negative signal that leads to a decline in stock markets globally and increasingly inefficient stock markets (Lalwani \& Meshram, 2020). One of the reasons to sell stocks is to get capital gains. The pressure to sell stocks for the first time can slowly lower the stock price. On the other hand, in a pandemic condition, fears of falling stock prices prompted some investors to sell their stocks. However, several other investors (i.e., risk-takers), consider this an opportunity and instead buy stocks.

\section{RESEARCH METHODS}

\subsection{Research Type}

This research is a descriptive study because it aims to obtain an overview of individual investors' behavioral factors in making investment decisions in stocks listed on the Indonesia Stock Exchange during the Covid-19 pandemic. Based on this approach, this research is quantitative/positivist research.

Table 1 exhibits the variables used in this study.
Table 1. Operational definition

\begin{tabular}{cll}
\hline Factor & \multicolumn{1}{c}{ Definition } & \multicolumn{1}{c}{ Size } \\
\hline Heuristic & The main rules that form & $\bullet$ Representative \\
& $\begin{array}{ll}\text { the basis of easier decision } \\
\text { making }\end{array}$ & $\bullet$ Overconfidence \\
& & $\bullet$ Gambler's fallacy \\
& & $\bullet$ Ability bias
\end{tabular}

\subsection{Data}

The target population chosen is individual investors who make investment decisions in stocks on the Indonesia Stock Exchange during the Covid-19 pandemic. The sampling methods used were convenience sampling and snowball sampling. This study used 186 samples of individual stock investors listed on the Indonesia Stock Exchange during the Covid-19 pandemic. The data were then processed by factor analysis using SPSS 18.0 software.

\section{RESULTS AND DISCUSSIONS}

\subsection{Respondent profiles}

The results of the data processing of respondents are presented in Table 2. Based on gender, male invests more than female. The highest education level of Bachelor's degree shows that knowledge about investment in Indonesia is mainly received during university study so that the maturity to invest is peaked at Bachelor's education level. The lowest income of respondents was below 1 million $\mathrm{Ru}$ piah, with the smallest percentage at $11 \%$. The distribution of total investment in 2020 and 2021 is more than 30 million and increasing in 2021.

Table 2. Distribution results of respondent

\begin{tabular}{llll}
\hline Category & Selection & Freq. & $\%$ \\
\hline \multirow{2}{*}{ Gender } & Male & 115 & $62 \%$ \\
\cline { 2 - 4 } & Female & 71 & $38 \%$ \\
\hline \multirow{4}{*}{ Age } & $18-25$ & 65 & $35 \%$ \\
\cline { 2 - 4 } & $26-35$ & 58 & $31 \%$ \\
\cline { 2 - 4 } & $36-45$ & 24 & $13 \%$ \\
\cline { 2 - 4 } & $46-55$ & 11 & $6 \%$ \\
\cline { 2 - 4 } & Over 55 & 28 & $15 \%$ \\
\hline \multirow{2}{*}{ Status } & Not yet married & 106 & $57 \%$ \\
\cline { 2 - 4 } & Married & 74 & $40 \%$ \\
\hline
\end{tabular}




\begin{tabular}{|c|c|c|c|}
\hline & Divorce & 6 & $3 \%$ \\
\hline \multirow{5}{*}{ Education } & SMA / SMK & 28 & $15 \%$ \\
\hline & DIPLOMA & 11 & $6 \%$ \\
\hline & Bachelor's degree & 87 & $47 \%$ \\
\hline & Master (S2) & 48 & $26 \%$ \\
\hline & PhD degree (S3) & 11 & $6 \%$ \\
\hline \multirow{5}{*}{ Profession } & $\begin{array}{l}\text { Government em- } \\
\text { ployees }\end{array}$ & 30 & $16 \%$ \\
\hline & Private employees & 45 & $24 \%$ \\
\hline & Entrepreneur & 43 & $23 \%$ \\
\hline & Professional & 24 & $13 \%$ \\
\hline & Others & 45 & $24 \%$ \\
\hline \multirow{3}{*}{$\begin{array}{l}\text { Length of } \\
\text { work }\end{array}$} & Under 5 years & 78 & $42 \%$ \\
\hline & $1-10$ years & 28 & $15 \%$ \\
\hline & More than 10 years & 47 & $25 \%$ \\
\hline \multirow{4}{*}{$\begin{array}{l}\text { Income per } \\
\text { month }\end{array}$} & Below 1 million & 20 & $11 \%$ \\
\hline & 1-3 million & 35 & $19 \%$ \\
\hline & 4-8 million & 60 & $32 \%$ \\
\hline & Above 8 million & 71 & $38 \%$ \\
\hline \multirow{5}{*}{$\begin{array}{l}\text { Duration of } \\
\text { stock in- } \\
\text { vestment }\end{array}$} & Less than 1 year & 58 & $31 \%$ \\
\hline & $1-2$ years & 58 & $31 \%$ \\
\hline & $3-4$ years & 20 & $11 \%$ \\
\hline & $5-10$ years & 22 & $12 \%$ \\
\hline & More than 10 years & 28 & $15 \%$ \\
\hline \multirow{2}{*}{$\begin{array}{l}\text { Have At- } \\
\text { tended } \\
\text { Training }\end{array}$} & Yes & 102 & $55 \%$ \\
\hline & Never & 84 & $45 \%$ \\
\hline \multirow{6}{*}{$\begin{array}{l}\text { Total money } \\
\text { invested }\end{array}$} & Below 2 million & 39 & $21 \%$ \\
\hline & 2-4 million & 19 & $10 \%$ \\
\hline & 5-10 million & 32 & $17 \%$ \\
\hline & 10-20 million & 24 & $13 \%$ \\
\hline & 21-30 million & 9 & $5 \%$ \\
\hline & $\begin{array}{l}\text { More than } 30 \text { mil- } \\
\text { lion }\end{array}$ & 63 & $34 \%$ \\
\hline \multirow{6}{*}{$\begin{array}{l}\text { Total } \\
\text { amount of } \\
\text { money in- } \\
\text { vested in } \\
2020\end{array}$} & Below 2 million & 52 & $28 \%$ \\
\hline & 2-4 million & 22 & $12 \%$ \\
\hline & 5-10 million & 33 & $18 \%$ \\
\hline & $10-20$ million & 15 & $8 \%$ \\
\hline & 21-30 million & 11 & $6 \%$ \\
\hline & $\begin{array}{l}\text { More than } 30 \text { mil- } \\
\text { lion }\end{array}$ & 52 & $28 \%$ \\
\hline
\end{tabular}

Source: Results of data processing

\subsection{Descriptive Analysis}

Table 3 exhibits the mean and standard deviation values.
Table 3. Descriptive Variable

\begin{tabular}{llll}
\hline Factors & $\mathrm{N}$ & Mean & $\begin{array}{l}\text { Std. } \\
\text { Devia- } \\
\text { tion }\end{array}$ \\
\hline Representativeness 1 & 186 & 4.941 & 1.051 \\
\hline Representativeness2 & 186 & 4.930 & 1.003 \\
\hline Overconfidence & 186 & 4.769 & 0.904 \\
\hline Anchoring1 & 186 & 4.898 & 0.861 \\
\hline Anchoring2 & 186 & 4.565 & 1.109 \\
\hline Gambler's fallacy & 186 & 4.194 & 1.156 \\
\hline Ability bias 1 & 186 & $\mathbf{5 . 0 9 7}$ & 1.081 \\
\hline Ability bias 2 & 186 & 4.425 & $\mathbf{1 . 3 3 9}$ \\
\hline Average & \multicolumn{4}{c}{4.727} & 1.063 \\
\hline Source: Results of data processing & \\
Note: bold $=$ highest value, italicized $=$ lowest value
\end{tabular}

A heuristic is defined as a main rule of thumb for decision-making in uncertain conditions, especially in complex conditions when investing in stocks listed on the Indonesia Stock Exchange during a pandemic. Based on Table 3 , the heuristic variable gets the highest mean value of 5.097 in the statement, "You prefer to buy domestic than foreign stocks because more information about domestic stocks is available.", While the lowest mean value of 4.194 is found in the statement, "You are able to anticipate the best and worst market rate of return on the Indonesia Stock Exchange."

The highest standard deviation value of 1.339 is found in the statement, "You consider information from close friends and relatives, as a reliable reference for your investment decisions". Meanwhile, the lowest standard deviation value of 0.904 is found in the statement, "You are relying on past market experience for your future investment". The total mean value is 4.727 , indicating that there is no mean below 4 for each dimension. While the average standard deviation is 1.063 , indicating that the respondents' answers vary.

After processing the data for the validity and reliability of the questionnaire, some invalid indicators were discarded. Indicators discarded from the heuristic variable are Representativeness 1, Gambler's Fallacy, and Ability bias 2. 


\subsection{Factor Analysis}

The results of factor analysis are demonstrated by KMO and Bartlett's Test and Variable Extraction Analysis.

Table 4. KMO and Bartlett's Test

\begin{tabular}{lll}
\hline $\begin{array}{l}\text { Kaiser-Meyer-Olkin Measure of Sam- } \\
\text { pling Adequacy. }\end{array}$ & 0.660 \\
\hline \multirow{3}{*}{$\begin{array}{l}\text { Bartlett's Test of } \\
\text { Sphericity }\end{array}$} & Approx. Chi-Square & 102.909 \\
\cline { 2 - 3 } & $\mathrm{df}$ & 10 \\
\cline { 2 - 3 } & Sig. & 0.00
\end{tabular}

Source: Results of data processing

Table 4 shows the Keizer-Meyer-Olkin Measure of Sampling Adequacy figure of 0.660 which is greater than 0.500 and sig. 0.000, meaning that the collection of these variables can be processed further. Table 5.4 shows that the five variables are extracted into two factors only, then: the variance of the first factor is $39.136 \%$ and the second is $21.682 \%$. These two new factors can explain $60.817 \%$ of the variability of the five factors.

Table 5. Total Variance Explained above 60\%

\begin{tabular}{cccc}
\hline Comp. & \multicolumn{3}{c}{ Extraction Sums of Squared Loadings } \\
\hline & Total & \% of Variance & Cum\% \\
\hline 1 & 1,957 & 39,136 & 39,136 \\
\hline 2 & 1,084 & 21,682 & 60,817 \\
\hline
\end{tabular}

Source: Results of data processing

Table 6 shows the change in the composition of each factor's variance contribution, which is the result of the rotation of the first factor of $39.108 \%$ and the second factor $21.709 \%$.

Table 6. Rotation Sums of Square Loading

\begin{tabular}{llll}
\hline $\begin{array}{l}\text { No. } \\
\text { Factor }\end{array}$ & \multicolumn{2}{l}{ Rotation Sums of Squared Loadings } \\
\hline & Total & \% of Variance & $\begin{array}{l}\text { Cumula- } \\
\text { tive\% }\end{array}$ \\
\hline 1 & 1.955 & 39.108 & 39.108 \\
\hline 2 & 1.085 & 21.709 & 60.817 \\
\hline
\end{tabular}

Source: Results of data processing

Based on Table 7 , the equation for the two factors is as follows:

F1 (Past Experience) $=0.726 \mathrm{X} 1$ (Representativeness 2$)+0.700 \mathrm{X} 2$ (Overconfidence)
$+0.755 \mathrm{X} 3$ (Anchoring1) + 0.594X3 (Anchoring2)

F2 $($ Learning orientation $)=0.910 \mathrm{X} 1($ Abilitybias 1)

Table 7 Component score coefficient matrix

\begin{tabular}{lll}
\hline \multirow{2}{*}{ Factor } & \multicolumn{2}{c}{ Component } \\
\cline { 2 - 3 } & 1 & 2 \\
\hline Representativeness2 & 0.726 & \\
Overconfidence & 0,700 & \\
Anchoring1 & 0.755 & \\
Anchoring2 & 0.594 & $-0,460$ \\
Abilitybias 1 & & 0.910 \\
\hline
\end{tabular}

Source: Results of data processing

\subsection{Behavior Factors for Stock Investors}

The factor analysis results that have been carried out are two factors: the past experience and the learning orientation. These two factors are presented in Table 7. The first factor is the past experience on the historical performance of stocks as the basis for making individual investor investment decisions in the future. A study supporting this dimension was conducted by Parveen, Wajid, Abdul, \& Jamil (2020) explains that investors over-generalize the performance of past stocks in the stock market. Furthermore, investors will be more interested in stocks that have an increasing pattern in the past. This factor consists of three dimensions, namely representativeness, overconfidence, and anchoring.

The factor analysis results that have been carried out are two factors: the past experience and the learning orientation. These two factors are presented in Table 7. The first factor is the past experience on the historical performance of stocks as the basis for making individual investor investment decisions in the future. A study supporting this dimension was conducted by Parveen et al. (2020) explains that investors over-generalize the performance of past stocks in the stock market. Furthermore, investors will be more interested in stocks that have an increasing pattern in the past. This factor consists of three dimensions, namely representativeness, overconfidence, and anchoring. 
Representativeness is represented by investors who strive to represent the past as evidence used for consideration in decision-making. In addition, investors who use the representative dimension heuristic depend heavily on stock quality to improve the fundamental assessment of stock performance. Investors often make decisions based on limited data and use past trends in small sample sizes. As a result, investors choose the most representative stocks that describe the quality of the stocks they want.

Anchoring refers to predicting future results by considering recent experiences and being optimistic when the market is on an uptrend and pessimistic when it is on a downtrend. Holders tend to rely on only one piece of information for decision-making. In addition, investors focus on popular stocks because the information is fascinating and makes them believe that the stock is experiencing growth.

Overconfidence refers to the behavior of investors who tend to overtrade in the market to get a higher return. They rely on personal information and react less to information about stock price changes and ignore company fundamentals.

The second factor is the learning orientation factor which contains the Ability bias 1 dimension. The ability bias occurs when investors have excessive available information, so in stock trading, this bias manifests itself through investment preferences in local companies where investors are used to obtaining information easily.

Individual investors will consider the two heuristic behavioral factors above in making stock investment decisions (selling or buying) in companies listed on the Indonesia Stock Exchange during the Covid-19 pandemic. A pandemic makes some investors deciding to sell stocks at low prices because they feel pessimistic about their investment (Huang et al., 2020). One of the reasons to sell the stocks is to earn capital gains. The pressure to sell stocks the first time around can slowly reduce the stock price and then produce a higher return. In a pandemic condition, fears over the declining stock price urge some investors to sell their shares. However, other investors, namely investors who dare to take risks (risk takers), consider this an opportunity and instead buy stocks. The assumption used is that a pandemic is a temporary condition so that when the pandemic is over, the stock price increases.

\section{CONCLUSION}

Individual investors consider two heuristic factors when making stock investment decisions during the Covid-19 pandemic. The first factor is "past experiences" and the second factor is "learning orientation". Individual investors consider the two heuristic factors above in making stock investment decisions (selling or buying) in companies listed on the Indonesia Stock Exchange during the Covid19 pandemic.

A limitation in this study is the inability to examine the magnitude of the influence of each of these factors on investment decisions, so that the impact of these factors on the investment performance of stock investors in the Indonesia Stock Exchange cannot be measured.

\section{REFERENCES}

Batmunkh, M., Choijil, E., Paulo, J., Espinosa-méndez, C., \& Wong, W. 2020. Does herding behavior exist in the Mongolian stock market?. Pacific-Basin Finance Journal, 62(May): 101352.

Bousselmi, W., Sentis, P., \& Willinger, M. 2019. How do markets react to ( un ) expected fundamental value shocks?. Journal of Behavioral and Experimental Finance, 23: 90-113.

Fan, Y. 2020. Does Adversity A ff ect Long-Term Financial Behaviour? Evidence from China' $\mathrm{s}$ Rustication Programme *. Journal of Urban Economics, 115: 103218.

Hoffmann, A. O. I., Post, T., \& Pennings, J. M. E. 2013. Individual investor perceptions and behavior during the financial crisis. Journal of Banking and Finance, 37(1): 60-74.

Huang, C., Wang, Y., Li, X., Ren, L., Zhao, J., Hu, Y., ... Gu, X. 2020. Articles Clinical features of patients infected with 2019 novel coronavirus in Wuhan, China, 6736(20): 1-10.

Istanbul, C., Yurttadur, M., \& Ozcelik, H. 2019. 
Evaluation of the Financial Individual In- from Behavioral The Case of Istanbul 3rd vestors World Conference on Technology, Finance: ScienceDirect. Procedia Computer Science, 158: 761-765.

Lalwani, V. and Meshram, VV 2020 'Stock Market Efficiency in the Time of COVID-19: Evidence from Industry Stock Returns', International Journal of Accounting \& Finance Review, 5 (2): 40-44.

Méndez, C., E., \& Arias, J. 2021. COVID-19 effect on herding behaviour in European Capital Markets. Finance Research Letters, 101787.

Parveen, S., Wajid, Z., Abdul, Q., \& Jamil, S. 2020. Exploring market overreaction , investors sentiments and investment decisions in an emerging stock market. Borsa Istanbul Review, 20(3): 224235.

Rihards, E., Savin, A., \& Lublóy, Á. 2019. Herding behaviour in an emerging market: Evidence from the Moscow Exchange. Emerging Markets Review, 38(December 2018): 468-487.

World Bank. 2020. The Global Economic Outlook During the COVID-19 Pandemic: A Changed World. The World Bank. https://www.worldbank.org/en/news/feature/2020/0 6/08/the-global-economic-outlook-during-thecovid-19-pandemic-a-changed-world

www.who.int. (2021). Retrieved from www.who.int 